\title{
Pharmacokinetics and Pharmacodynamic Effects of Nemvaleukin Alfa, a Selective Agonist of the Intermediate- Affinity IL-2 Receptor, in Cynomolgus Monkeys ${ }^{[}$
}

\author{
Jared E. Lopes, Lei Sun, Heather L. Flick, Erin A. Murphy, and Heather C. Losey \\ Alkermes, Inc., Waltham, Massachusetts
}

Received March 12, 2021; accepted August 4, 2021

\begin{abstract}
Nemvaleukin alfa (nemvaleukin, ALKS 4230) is a novel cytokine created by the fusion of circularly permuted interleukin-2 (IL-2) to the IL-2R $\alpha$ subunit of the IL-2 receptor (IL-2R) complex that confers selectivity for the intermediate-affinity IL-2R expressed on $\mathrm{CD}^{+} \mathrm{T}$ cells and natural killer (NK) cells. The pharmacokinetics and selective pharmacodynamic properties of nemvaleukin have been demonstrated using in vitro and in vivo mouse models. The pharmacokinetic/pharmacodynamic effects of nemvaleukin on immune cell subtypes were evaluated in cynomolgus monkeys after intravenous and subcutaneous administration to inform dose selection and predict pharmacodynamic effects in humans. Male drug-naïve cynomolgus monkeys $(N=15)$ were administered either single-dose $(0.3 \mathrm{mg} / \mathrm{kg}$ i.v.; $0.3 \mathrm{mg} / \mathrm{kg}$ or $1.0 \mathrm{mg} /$ $\mathrm{kg} \mathrm{s.c.)}$ or repeated doses $(0.1 \mathrm{mg} / \mathrm{kg}$ i.v. on days $1-5$ or $0.5 \mathrm{mg} /$ $\mathrm{kg}$ s.c. on days 1 and 4) of nemvaleukin. Serial blood samples were collected for pharmacokinetic assessment, immunophenotyping by flow cytometry, and profiling of serum cytokines. Repeat-dose subcutaneous administration of nemvaleukin with less frequent dosing resulted in total systemic exposure and trough serum concentrations comparable to those seen with intravenous administration, with lower
\end{abstract}

peak serum concentrations. Transient elevation of interferon- $\gamma$ and IL- 6 peaked at 2 and 8 hours after intravenous and subcutaneous administration, respectively. Selective expansion of immunoprotective central memory, effector memory, terminal effector $\mathrm{CD}^{+}{ }^{\mathrm{T}}$ cells, and $\mathrm{CD} 56^{+} \mathrm{NK}$ cells, and minimal expansion of immunosuppressive $\mathrm{CD} 4^{+} \mathrm{CD} 25^{+} \mathrm{FoxP}^{+}$regulatory $\mathrm{T}$ cells was observed after both intravenous and subcutaneous administration. These data support the ongoing clinical evaluation of intravenous and subcutaneous nemvaleukin.

\section{SIGNIFICANCE STATEMENT}

Administration of the novel interleukin-2 receptor agonist nemvaleukin alfa to cynomolgus monkeys resulted in selective expansion of immune effector cells, including $\mathrm{CD}^{+} \mathrm{T}$ and natural killer cells with minimal effects on immunosuppressive $\mathrm{CD} 4^{+}$ regulatory $\mathrm{T}$ cells, confirming the design of nemvaleukin and highlighting its potential as a cancer immunotherapy. Subcutaneous administration of nemvaleukin achieved systemic exposure and immunostimulatory effects similar to those observed after more frequent intravenous dosing and may represent a practical alternative in a clinical setting.

\section{Introduction}

Interleukin-2 (IL-2) was originally discovered as a T cell growth factor based on its ability to promote the growth of lymphocytes in vitro (Boyman and Sprent, 2012). However, it is now appreciated that IL-2 plays a much larger role in maintaining immune homeostasis, given that it is required for the development and function of immunosuppressive $\mathrm{CD} 4{ }^{+} \mathrm{CD} 25^{+} \mathrm{CD} 127^{\text {low/ }}-\mathrm{FoxP}^{+}$ regulatory $\mathrm{T}$ cells $\left(\mathrm{CD} 4^{+} \mathrm{T}_{\text {regs }}\right.$ ), as well as the function of immune

This work was supported by funding provided by Alkermes, Inc, Waltham, MA. Lei Sun, Jared E. Lopes, Heather L. Flick, Erin A. Murphy, and Heather C. Losey are employees and stockholders of Alkermes, Inc.

https://dx.doi.org/10.1124/jpet.121.000612.

S This article has supplemental material available at jpet.aspetjournals.org. effector cells, including conventional $\mathrm{CD}^{+}{ }^{+} \mathrm{T}$ cells, $\mathrm{CD}^{+} \mathrm{T}$ cells, natural killer (NK) cells, and B cells (Waldmann, 2006; Boyman and Sprent, 2012; Choudhry et al., 2018). Presentation of tumor antigens by mature dendritic cells to antigen-specific $\mathrm{CD} 4^{+}$and $\mathrm{CD} 8^{+} \mathrm{T}$ cells in secondary lymphoid tissues results in the expression of high-affinity IL-2R complexes and the local production of $\mathrm{IL}-2$, supporting the expansion of tumor antigen-specific T cells (Boyman and Sprent, 2012). NK cells, which are cytotoxic for major histocompatibility complexes class I-deficient tumor cells, also express high- and intermediate-affinity IL-2R complexes. However, high-affinity IL-2R complexes are constitutively expressed on $\mathrm{CD}^{+} \mathrm{T}_{\text {regs }}$ (Boyman and Sprent, 2012). Thus, by activating and expanding $\mathrm{CD} 4^{+} \mathrm{T}_{\text {regs }}$, as well as conventional $\mathrm{CD} 4^{+} \mathrm{T}$ cells, $\mathrm{CD} 8^{+} \mathrm{T}$ cells, and NK cells, IL-2 exerts

ABBREVIATIONS: aldesleukin, recombinant IL-2; AUC, area under the concentration-time curve; AUC $\infty$, AUC from time 0 to infinity; $A \cup C_{t}$, area under the concentration-time curve from time 0 to the time of the last measurable serum concentration estimated by the linear trapezoidal rule; $\mathrm{AUC}_{\text {total }}$, total $\mathrm{AUC}$ over the entire dosing period; $\mathrm{AUMC}$, area under the moment curve; $\mathrm{AUMC}_{\infty}$, area under the moment curve from 0 to infinity; $C D$, cluster of differentiation; $C L$, total body clearance; Fc, fragment crystallizable region; FoxP3, forkhead box P3; IFN $\gamma$, interferon- $\gamma$; IL, interleukin; IL-2R, interleukin-2 receptor; LLOQ, lower limit of quantitation; mAb, monoclonal antibody; MRT, mean residence time; MSD, Meso Scale Discovery; NK, natural killer; nemvaleukin, nemvaleukin alfa (ALKS 4230); PD, pharmacodynamics; PK, pharmacokinetics; $Q C$, quality control; $t_{1 / 2}$, terminal elimination half-life; $T_{\max }$, time to $C_{\max } ; T_{\text {reg }}$, regulatory $T$ cell; ULOQ, upper limit of quantitation; $\mathrm{Vd}_{\mathrm{ss}}$, volume of distribution at steady state. 
dual regulatory (e.g., on immunosuppressive $\mathrm{CD}^{+} \mathrm{T}_{\text {regs }}$ ) and stimulatory (e.g., on immune effector $\mathrm{CD} 8^{+} \mathrm{T}$ cells and NK cells) effects on the immune cells that are integral to the cancer immunity cycle. Recombinant IL-2 (aldesleukin) was among the first immunotherapies to be approved for the treatment of advanced/metastatic renal cell carcinoma and melanoma. Paradoxically, the high doses required for antitumor activity have been associated with activation and expansion of high-affinity IL-2R-expressing CD4 ${ }^{+} \mathrm{T}_{\text {regs }}$ that are hypothesized to hinder antitumor efficacy. Furthermore, widespread use of high-dose IL-2 has been limited due to its association with potentially life-threatening acute toxicities (e.g., vascular leak syndrome that can lead to liver cell damage and renal failure), which may be explained by the expression of the high-affinity IL-2R complex on endothelial cells (Atkins et al., 1999; Boyman and Sprent, 2012; Sim et al., 2014; Amaria et al., 2015; Choudhry et al., 2018).

Leveraging the immunostimulatory effects of IL-2, while at the same time mitigating the protumor activation and expansion of $\mathrm{CD}^{+} \mathrm{T}_{\text {regs }}$ and avoiding the toxicity associated with high doses, is hypothesized to enhance the immunotherapeutic potential of IL-2 (Ahmadzadeh and Rosenberg, 2006; Skrombolas and Frelinger, 2014). This strategy can be achieved through selective targeting of the intermediate-affinity IL-2R, comprising IL-2R $\beta$ and common $\gamma$ chains expressed on immune effector cells, including $\mathrm{CD}^{+} \mathrm{T}$ cells and NK cells, while avoiding activation of the high-affinity IL-2R, comprising IL-2R $\alpha$ (also known as CD25), IL-2R $\beta$, common $\gamma$ chains expressed on $\mathrm{CD}^{+}{ }^{+} \mathrm{T}_{\text {regs }}$, and endothelial cells (Boyman and Sprent, 2012).

Nemvaleukin alfa (nemvaleukin, ALKS 4230) is a novel, engineered cytokine that was created by fusing circularly permuted IL-2 to the extracellular domain of the IL-2R $\alpha$ subunit of the IL-2R complex (Fig. 1A). In comparison with IL-2, nemvaleukin selectively engages the intermediate-affinity IL-2R complex that is expressed on subsets of $\mathrm{CD}^{+} \mathrm{T}$ cells and NK cells and is sterically occluded from binding to the high-affinity IL-2R complex that is expressed preferentially on $\mathrm{CD} 4^{+} \mathrm{T}_{\text {regs }}$
(Fig. 1B) (Antony and Restifo, 2005; Sun et al., 2019; Lopes et al., 2020). Data from in vitro human studies and in vivo mouse studies have shown that, compared with recombinant human IL-2, nemvaleukin selectively activates and expands circulating $\mathrm{NK}$ cells and memory-phenotype $\mathrm{CD}^{+} \mathrm{T}$ cells with negligible effects on $\mathrm{CD} 4{ }^{+} \mathrm{T}_{\text {regs }}$ (Lopes et al., 2020). This selective expansion of immune effector cells with antitumor function(s) has promising therapeutic potential, and clinical studies of nemvaleukin, as monotherapy or in combination with the anti-programmed death-1 checkpoint inhibitor pembrolizumab, in patients with advanced solid tumors are ongoing [ARTISTRY-1 (NCT02799095); ARTISTRY-2 (NCT03861793); ION-01 nemvaleukin (NCT04144517)].

The present study examines the pharmacokinetics (PK) and pharmacodynamic (PD) effects of nemvaleukin on multiple immune cell subtypes (including circulating $\mathrm{CD}^{+} \mathrm{T}$ cells, NK cells, CD4 ${ }^{+} \mathrm{T}$ cells, and $\mathrm{CD} 4^{+} \mathrm{T}_{\text {regs }}$ ) in cynomolgus monkeys after intravenous and subcutaneous routes of administration. The PK-PD relationship in cynomolgus monkeys is expected to inform dose selection and predict PD effects in humans.

\section{Materials and Methods}

\section{Animals}

Male drug-naïve cynomolgus monkeys $(N=15)$ (Covance Laboratories, Inc., Madison, WI and Covance Research Products, Inc., Alice, TX) aged 2-4 years were housed in stainless steel cages at ambient temperatures under a 12-hour light/dark cycle and fed a certified primate diet with water ad libitum. After acclimation to study conditions over a 1- to 4-day period, animals were selected for testing based on their overall health and body weight, which ranged from $2.4 \mathrm{~kg}$ to $3.4 \mathrm{~kg}$ at baseline. All procedures were conducted in compliance with the Animal Welfare Act Regulations (9 CFR 3).

\section{Study Design and Dosing Schedule}

All dosing and sample collections were conducted at Covance Laboratories. Individual doses of nemvaleukin were calculated based on body weight as measured on the day of dosing in the single-dose study,
Fig. 1. Mechanism of action of nemvaleukin. (A) Visualization of spatial distance between unfused IL-2 and IL-2R (with native $\mathrm{N}$-termini and $\mathrm{C}$ termini labeled). (B) Nemvaleukin selectively engages the intermediate-affinity IL-2R complex that is expressed on subsets of $\mathrm{CD}^{+} \mathrm{T}$ cells and NK cells and is sterically occluded from binding to the highaffinity IL-2R complex that is expressed on $\mathrm{CD}^{+}{ }^{+} \mathrm{T}_{\text {regs }}$.
A
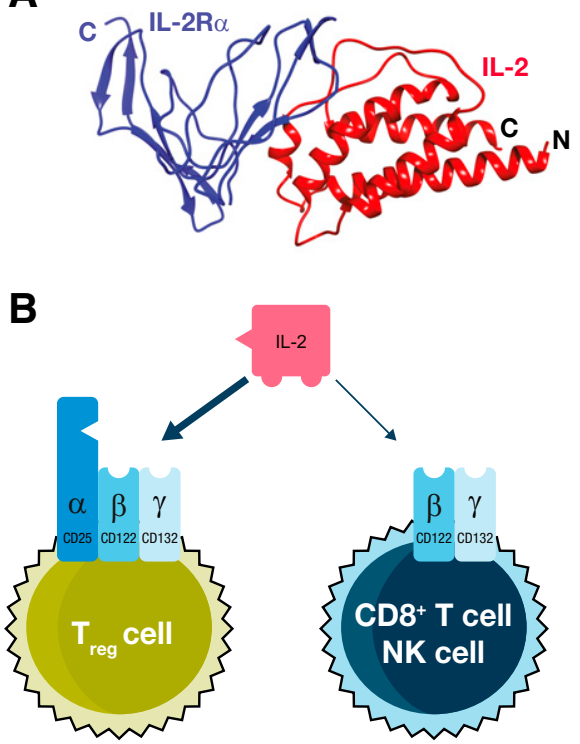

High-affinity receptor-bearing cell
Intermediate-affinity receptor-bearing cell
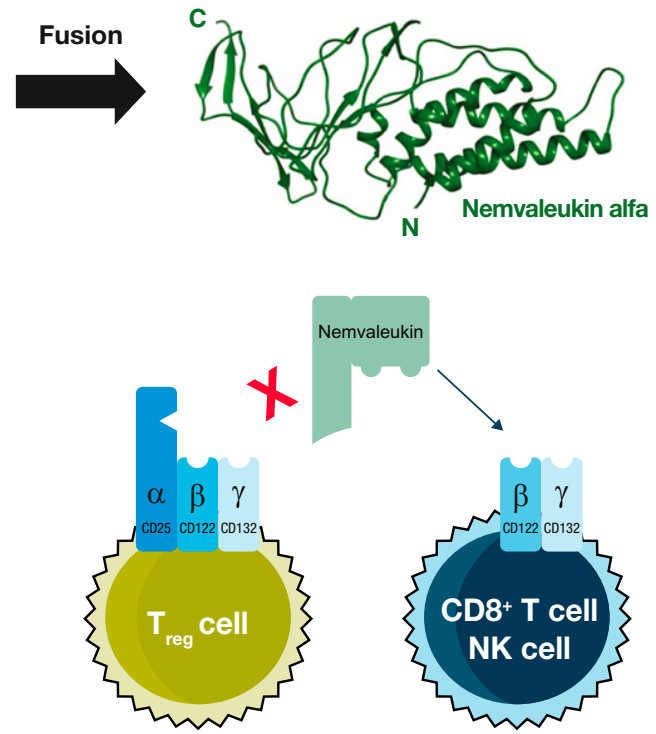

High-affinity receptor-bearing cell
Intermediate-affinity receptor-bearing cell 
and the first day of dosing in the repeat-dose study. Animals were not fasted prior to dosing. In the single-dose study, nemvaleukin was administered intravenously at $0.3 \mathrm{mg} / \mathrm{kg}$ or subcutaneously at 0.3 or $1.0 \mathrm{mg} / \mathrm{kg}$ (three animals per dose group; Supplemental Fig. 1A). In the repeat-dose study, nemvaleukin was administered intravenously at $0.1 \mathrm{mg} / \mathrm{kg}$ once daily for 5 consecutive days on days $1-5$ (group 1) or subcutaneously at $0.5 \mathrm{mg} / \mathrm{kg}$ on day 1 and day 4 (group 2; three animals per dose group; Supplemental Fig. 1B). The intravenous dose was administered via a saphenous vein using a needle and catheter set as a slow push (over $\geq 1$ minute). The subcutaneous dose was administered via syringe and needle in the midscapular region. Blood samples to determine serum concentrations of nemvaleukin and selected cytokines (approximately $2 \mathrm{ml}$ ) were collected from the femoral vein into tubes without anticoagulant at predefined time points (Supplemental Fig. 1). Whole blood samples for immunophenotyping (approximately $2 \mathrm{ml}$ ) were collected into tubes containing potassium EDTA anticoagulant at predefined time points (Supplemental Fig. 1).

\section{Pharmacokinetic Data Analysis}

Serum concentrations of nemvaleukin were analyzed by an independent bioanalytic laboratory (Covance, Chantilly, VA) via electrochemiluminescence assay using a sandwich immunoassay format on the Meso Scale Discovery (MSD) (Meso Scale Diagnostics, LLC, Rockville, MD) platform. The capture antibody, anti-human IL-2 R $\alpha$ monoclonal antibody (mAb; clone 24204, mouse IgG1, catalog number MAB623, R and D Systems Inc., Minneapolis, MN), was coated onto a single-spot 96-well standard bind MSD plate and incubated for at least 12 hours at $2-8^{\circ} \mathrm{C}$. The plate was washed and blocked before samples were added. Nemvaleukin in the sample was bound to the capture antibody immobilized on the working electrode surface and was detected using the SULFO-TAG anti-hIL-2 antibody MAB202 (R and D Systems Inc., catalog number MAB202, clone \#5334). After a 1-hour incubation, the plates were washed, and MSD read buffer (Meso Scale Diagnostics) was added. The plate was read in an MSD Sector Imager 6000 (Meso Scale Diagnostics) instrument, and data were analyzed using a five-parameter logistic function with $1 / \mathrm{y}^{2}$ weighting in Watson software version 7.4.1 (range of quantitation $1-15 \mathrm{ng} / \mathrm{ml}$; Thermo Scientific). The assay had a lower limit of quantitation (LLOQ) of $1.0 \mathrm{ng} / \mathrm{ml}$ and an upper limit of quantitation (ULOQ) of $15.0 \mathrm{ng} / \mathrm{ml}$. Precision and accuracy of the assay were evaluated by analyzing quality control (QC) samples at the LLOQ $(1.0 \mathrm{ng} / \mathrm{ml})$, low QC $(2.5 \mathrm{ng} / \mathrm{ml})$, medium QC $(5.0 \mathrm{ng} / \mathrm{ml})$, high QC $(11.0 \mathrm{ng} / \mathrm{ml})$, and ULOQ $(15.0 \mathrm{ng} / \mathrm{ml})$. Please refer to the Supplemental Methods for the validation data. Nemvaleukin was stable in monkey serum for up to 26 hours at room temperature and up to six freeze/thaw cycles, for up to 72 hours refrigerated at $2-8^{\circ} \mathrm{C}$, and for 3 months (99 days) at $60^{\circ} \mathrm{C}$ to $-80^{\circ} \mathrm{C}$.

PK parameters of nemvaleukin were calculated by a standard noncompartmental analysis method using Phoenix WinNonlin v6.4 (Pharsight, a Certara Company, Mountain View, CA). The following parameters were estimated after single-dose administration of nemvaleukin: $\mathrm{C}_{\max }$, time to $\mathrm{C}_{\max }\left(\mathrm{T}_{\max }\right)$, terminal elimination half-life $\left(t_{1 / 2}\right)$, area under the concentration-time curve from time 0 to the time of the last measurable serum concentration estimated by the linear trapezoidal rule $\left(\mathrm{AUC}_{\mathrm{t}}\right)$, AUC from time 0 to infinity $\left(\mathrm{AUC}_{\infty}\right.$; calculated as $\mathrm{AUC}_{\infty}=\mathrm{AUC}_{\mathrm{t}}+\mathrm{C}_{\mathrm{t}} / \lambda \mathrm{z}$, where $\mathrm{C}_{\mathrm{t}}$ is the last measurable serum concentration and $\lambda z$ is the terminal elimination rate constant estimated using log-linear regression of the terminal elimination phase of the concentration-time curve), mean residence time (MRT; calculated as $\mathrm{AUMC}_{\infty} / \mathrm{AUC}_{\infty}$, where $\mathrm{AUMC}_{\infty}$ is the area under the moment curve from 0 to infinity), total body clearance (CL; calculated as dose/ $\left.\mathrm{AUC}_{\infty}\right)$, volume of distribution at steady state $\left[\mathrm{Vd}_{\mathrm{ss}}\right.$; calculated as $\left(\mathrm{AUMC}_{\infty} / \mathrm{AUC}_{\infty}\right) \times \mathrm{CL}$, and absolute bioavailability after subcutaneous administration $\left[\% \mathrm{~F}\right.$, calculated as $\left(\left[\right.\right.$ mean $\mathrm{AUC}_{\infty \text { (s.c.) }} \times$ dose $\left._{(\text {i.v. }}\right] /$ $\left[\right.$ mean $\left.\left.\left.\mathrm{AUC}_{\infty(\text { i.v. }} \times \operatorname{dose}_{(\text {s.c. }}\right]\right) \times 100\right]$.

The following PK parameters were estimated after repeat-dose administration of nemvaleukin: $\mathrm{C}_{\max }, \mathrm{T}_{\max }, t_{1 / 2}, \mathrm{AUC}_{\mathrm{t}}$, and total $\mathrm{AUC}$ over the entire dosing period $\left(\mathrm{AUC}_{\text {total }}\right)$. For subcutaneous dosing, this was calculated as $\mathrm{AUC}_{72 \mathrm{~h} \text {,day } 1}+\mathrm{AUC}_{\mathrm{t} \text {,day } 4}$, and for intravenous dosing, this was estimated to lie between $\mathrm{AUC}_{\text {total }}\left[\mathrm{AUC}_{24 \mathrm{~h} \text {,day } 1 \times 4+} \times\right.$ $\mathrm{AUC}_{\mathrm{t} \text {,day } 5}$ (assuming $\mathrm{AUC}_{24 \mathrm{~h}}$ on days 2 , 3 , and $4=\mathrm{AUC}_{24 \mathrm{~h}}$ on day 1 )] and $\mathrm{AUC}_{\text {total }}\left[\mathrm{AUC}_{24 \mathrm{~h} \text {,day } 1}+\mathrm{AUC}_{24 \mathrm{~h} \text {,day } 5} \times 3+\mathrm{AUC}_{\mathrm{t} \text {,day } 5}\right.$ (assuming $\mathrm{AUC}_{24 \mathrm{~h}}$ on days 2,3 , and $4=\mathrm{AUC}_{24 \mathrm{~h}}$ on day 5)].

\section{Immune Cell Analyses by Flow Cytometry}

Assessment of Nemvaleukin in Vitro Potency on Primary Leukocytes. Leukocytes obtained from cynomolgus monkey whole blood after standard red blood cell lysis were counted, resuspended in $\mathrm{X}$-VIVO 10 media, plated, and incubated in the presence of decreasing concentrations of nemvaleukin (4-fold dilutions beginning at $150 \mathrm{nM}$ for samples intended for analysis of memory $\mathrm{CD} 8^{+} \mathrm{T}$ cells and 3-fold dilutions beginning at $20 \mathrm{nM}$ for samples intended for analysis of $\mathrm{CD}^{+} \mathrm{T}_{\text {regs }}$ and NK cells). Samples were stimulated or unstimulated for approximately 30 minutes in a $37^{\circ} \mathrm{C}, 5 \% \mathrm{CO}_{2}$ environment. After stimulation, cells were fixed, washed, fragment crystallizable region (Fc)-blocked, and stained with fluorescently conjugated antibodies specific for $\mathrm{CD}^{+}{ }^{+} \mathrm{T}_{\text {reg }}$, NK cell, or memory $\mathrm{CD}^{+} \mathrm{T}$ cell surface markers. After surface marker staining, cells were washed and permeabilized for subsequent intracellular staining steps before sample acquisition on a BD LSRFortessa X-20 (BD Biosciences, San Jose, CA). Antibodies and fluorescent dyes used are described in Supplemental Table 1. Markers used to identify immune cell populations are detailed in Supplemental Table 2.

Immunophenotyping of Whole Blood. Blood sample processing and immunophenotypic data acquisition were performed at Alkermes, Inc. (Waltham, MA) approximately 24 hours after sample collection. Leukocytes obtained from cynomolgus monkey whole blood after standard red blood cell lysis were counted, resuspended in $\mathrm{X}$-VIVO 10 media, and plated. Cells were then resuspended in viability stain buffer and incubated at room temperature, washed, Fcblocked, and surface-stained with fluorescently conjugated antibodies. Cells were washed and permeabilized for subsequent intracellular staining steps prior to sample acquisition on a BD LSRFortessa X-20 using a high-throughput sampler. Antibodies and fluorescent dyes used are listed in Supplemental Table $3 . \mathrm{CD}^{+} \mathrm{T}_{\text {regs }}$, NK, and naïve/ memory $\mathrm{CD}^{+}$and $\mathrm{CD}^{+} \mathrm{T}$ cell populations were identified using the markers described in Supplemental Table 4.

\section{Quantification of Serum Concentrations of Proinflammatory Cytokines}

The V-PLEX Proinflammatory Panel 1 NHP Kit (Meso Scale Diagnostics) was used to quantify concentrations of IL- $1 \beta$, IL-6, IL-8, IL10 , and interferon- $\gamma(\mathrm{IFN} \gamma)$ in monkey serum samples using an MSD SQ120 instrument.

\section{Results}

In Vitro Potency of Nemvaleukin on Activating Lymphocyte Populations. The in vitro potency of nemvaleukin on activating selected lymphocyte subsets, including $\mathrm{CD} 6^{+} \mathrm{NK}$ cells, memory subsets of $\mathrm{CD}^{+} \mathrm{T}$ cells, and $\mathrm{CD} 4^{+}$ $\mathrm{T}_{\text {regs }}$, in terms of the $\mathrm{EC}_{50}$, were similar between cynomolgus monkeys and humans (Table 1), suggesting that cynomolgus monkey is a pharmacologically relevant species for predicting immunologic activity in humans. Potencies for NK cells and $\mathrm{T}_{\text {regs }}$ were similar to each other and between the monkey and human samples, with $\mathrm{EC}_{50}$ values within the $0.5 \mathrm{nM}$ range, whereas $\mathrm{EC}_{50}$ values for memory $\mathrm{CD}^{+} \mathrm{T}$ cell subsets were in the 1 to $2 \mathrm{nM}$ range.

Pharmacokinetics of Nemvaleukin after SingleDose Administration. After a single intravenous bolus dose of $0.3 \mathrm{mg} / \mathrm{kg}$, serum nemvaleukin concentrations declined in a 
TABLE 1

Potency of nemvaleukin on selected lymphocyte subsets from cynomolgus monkey and human samples (Lopes et al., 2020)

\begin{tabular}{lcc}
\hline Lymphocyte Population & $\begin{array}{c}\text { Monkey } \\
\text { EC }_{50} \\
\text { Mean } \pm \text { S.D. }\end{array}$ & $\begin{array}{c}\mathrm{Human}^{\mathrm{a}} \\
\mathrm{EC}_{50} \\
\text { Mean } \pm \text { S.D. }\end{array}$ \\
\hline NK cells & $n M$ & $n M$ \\
Naïve CD8 ${ }^{+}$T cells & $0.47 \pm 0.22$ & $0.45 \pm 0.09$ \\
Central/transitional memory CD8 & + \\
T cells & $1.4 \pm 0.3$ & $2.2 \pm 1.0$ \\
Effector memory CD8 ${ }^{+}$T cells & $1.3 \pm 0.4$ & $1.1 \pm 0.1$ \\
Terminal effector CD8 ${ }^{+}$T cells & $2.0 \pm 1.0$ & $1.25 \pm 0.4$ \\
$\mathrm{~T}_{\text {regs }}$ & $1.7 \pm 0.8$ & $0.93 \pm 0.3$ \\
\hline
\end{tabular}

${ }^{\text {a }}$ Data generated from three separate experiments, each performed in triplicate, and the error represents S.D.

multiexponential manner, with a mean terminal $t_{1 / 2}$ of 49.5 hours and MRT of 12.8 hours (Fig. 2A, Table 2). The mean serum CL and mean $\mathrm{Vd}_{\mathrm{ss}}$ were $10.6 \mathrm{ml} / \mathrm{h} / \mathrm{kg}$ and $135 \mathrm{ml} / \mathrm{kg}$, respectively (Table 2). After a single subcutaneous dose of $0.3 \mathrm{mg} / \mathrm{kg}$ or $1 \mathrm{mg} / \mathrm{kg}$, serum concentrations of nemvaleukin peaked at 8 hours at both dose levels (Fig. 2A, Table 2). Systemic exposure to nemvaleukin, as measured by $\mathrm{C}_{\max }$ and $\mathrm{AUC}_{\infty}$, increased in a less than dose-proportional manner from $0.3 \mathrm{mg} / \mathrm{kg}$ to $1.0 \mathrm{mg} / \mathrm{kg}$ (Table 2). As a result, subcutaneous bioavailability was estimated to be $45 \%$ at $0.3 \mathrm{mg} / \mathrm{kg}$ and $28 \%$ at $1.0 \mathrm{mg} / \mathrm{kg}$ of nemvaleukin.

Pharmacokinetics of Nemvaleukin after RepeatDose Administration. After subcutaneous administration of nemvaleukin at $0.5 \mathrm{mg} / \mathrm{kg}, \mathrm{C}_{\max }$ of nemvaleukin was reached at 8 hours after the first dose on day 1 and at 2 or 8 hours after the second dose on day 4. Although peak serum concentrations of nemvaleukin after subcutaneous doses of $0.5 \mathrm{mg} / \mathrm{kg}$ were 2 - to 3 -fold lower than those after repeated intravenous doses of $0.1 \mathrm{mg} / \mathrm{kg}$, trough serum concentrations and $\mathrm{AUC}_{\text {total }}$ after two subcutaneous doses of $0.5 \mathrm{mg} / \mathrm{kg}$ (on days 1 and 4) were comparable to those after five daily intravenous doses of $0.1 \mathrm{mg} / \mathrm{kg}$ (on days 1-5; Fig. 2B, Table 3).

Pharmacodynamic Effects of Nemvaleukin. Repeat doses of intravenous and subcutaneous nemvaleukin resulted in notable increases in $\mathrm{CD}^{+} \mathrm{T}$ cells and NK cells, peaking on days $6-8$, whereas only modest increases in $\mathrm{CD} 4^{+} \mathrm{T}_{\text {regs }}$ were observed (Fig. 3, A and B). Elevated numbers of CD8 ${ }^{+}$T cells and $\mathrm{CD}^{+} 6^{+}$NK cells were sustained until day 14, at which point cell numbers returned to predose levels. The expansion of $\mathrm{CD} 8^{+} \mathrm{T}$ cells and CD56 ${ }^{+} \mathrm{NK}$ cells was similar between the two dosing regimens, with 6- and 4-fold increases, respectively. In contrast, approximately 2 -fold increases in $\mathrm{CD} 4^{+}$ $\mathrm{T}_{\text {regs }}$ were observed (Fig. 3B). Expression of the intracellular proliferation marker Ki-67 was also measured. Increased

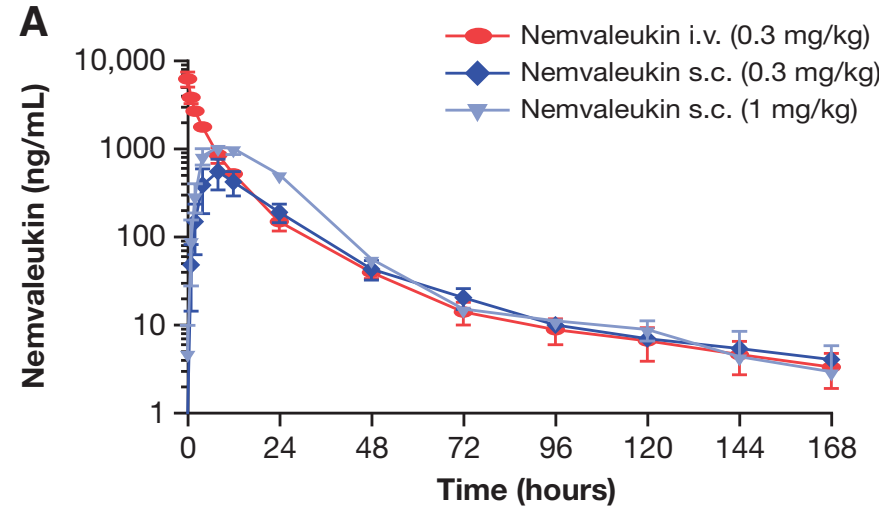

B

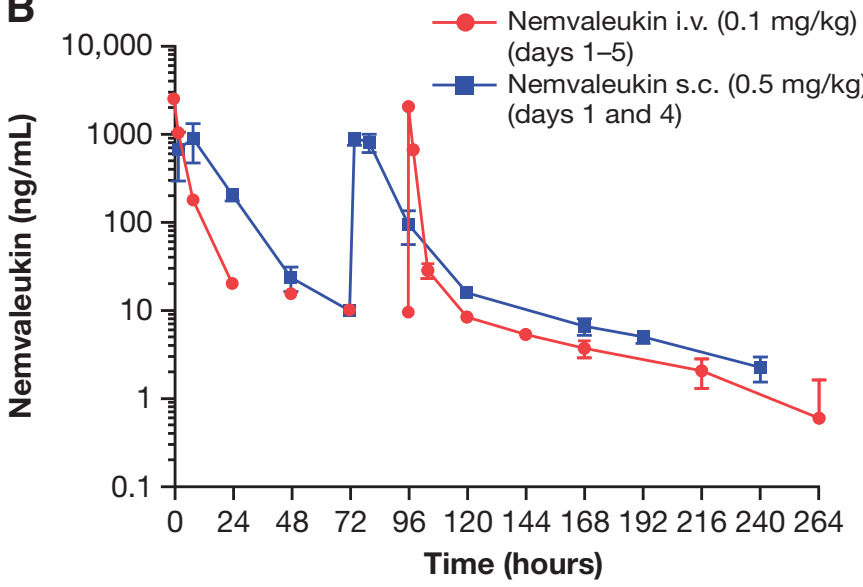

Fig. 2. Mean (+ S.D.) serum concentrations $(\mathrm{ng} / \mathrm{ml})$ of nemvaleukin in male cynomolgus monkeys after (A) single intravenous $(0.3 \mathrm{mg} / \mathrm{kg}$ ) or subcutaneous doses $(0.3,1.0 \mathrm{mg} / \mathrm{kg})$ and $(\mathrm{B})$ repeated intravenous $(0.1$ $\mathrm{mg} / \mathrm{kg}$ for 5 consecutive days, on days 1-5) or subcutaneous doses $(0.5$ $\mathrm{mg} / \mathrm{kg}$ on days 1 and 4$) . N=3$ per treatment group.

expression of Ki-67 was observed starting on day 3, and peaked at greater than $80 \%$ on day 6 for $\mathrm{CD}^{+} \mathrm{T}$ cells and CD56 ${ }^{+}$NK cells after intravenous administration (Fig. 3C). The peak of Ki-67 expression was not captured after subcutaneous administration, because several blood samples collected on days 6 and 7 froze during shipment, precluding their analyses. Increased Ki-67 expression was also observed in CD4 ${ }^{+}$ $\mathrm{T}_{\text {regs }}$, but to a lesser extent $(\sim 40 \%)$, consistent with the modest 2 -fold increases in cell numbers.

To assess whether particular subsets of $\mathrm{CD}^{+} \mathrm{T}$ cells responded more markedly to nemvaleukin, $\mathrm{CD} 8^{+} \mathrm{T}$ cells were categorized as naïve, central memory, effector memory, and terminal effector phenotype $\mathrm{CD}^{+}$populations according to the surface markers listed in Supplemental Table 4. Increased cell numbers after intravenous and subcutaneous administration

TABLE 2

PK parameters of nemvaleukin in male cynomolgus monkeys after a single intravenous $(0.3 \mathrm{mg} / \mathrm{kg})$ or subcutaneous $(0.3 \mathrm{or} 1.0 \mathrm{mg} / \mathrm{kg}) \mathrm{dose}$

\begin{tabular}{lcccccccc}
\hline Dose Route & Dose & $\mathrm{C}_{\max }$ & $\mathrm{T}_{\max }$ & $\mathrm{AUC}_{\infty}$ & $t_{1 / 2}$ & $\mathrm{MRT}$ & $\mathrm{CL}$ & $\mathrm{Vd}_{\mathrm{ss}}$ \\
\hline & $m g / \mathrm{kg}$ & $n g / \mathrm{ml}$ & $h$ & $\mathrm{hg} \cdot \mathrm{h} / \mathrm{ml}$ & $\mathrm{h}$ & $\mathrm{h}$ & $\mathrm{ml} / \mathrm{h} / \mathrm{kg}$ & $\mathrm{ml} / \mathrm{kg}$ \\
Intravenous & 0.3 & $6119 \pm 1188$ & $0.083(0.083,0.083)$ & $28,460 \pm 1230$ & $49.5 \pm 5.6$ & $12.8 \pm 1.9$ & $10.6 \pm 0.46$ & $135 \pm 16.6$ \\
Subcutaneous & 0.3 & $549 \pm 208$ & $8(8,8)$ & $12,931 \pm 3893$ & $61.9 \pm 4.6$ & $31.6 \pm 4.0$ & - & - \\
Subcutaneous & 1.0 & $1035 \pm 133$ & $8(8,8)$ & $26,878 \pm 2106$ & $37.3 \pm 19.4$ & $21.7 \pm 2.8$ & - \\
\hline
\end{tabular}

$N=3$ per treatment group

Mean ( \pm S.D.) for all parameters except $\mathrm{T}_{\max }$ [median (min, max)] 
TABLE 3

PK parameters of nemvaleukin in male cynomolgus monkeys after repeated intravenous $(0.1 \mathrm{mg} / \mathrm{kg}$ for 5 consecutive days, on days $1-5)$ or subcutaneous $(0.5 \mathrm{mg} / \mathrm{kg}$ on days 1 and 4$)$ doses

\begin{tabular}{|c|c|c|c|c|c|c|c|c|}
\hline Dose route & Dose & Day & $\mathrm{C}_{\max }$ & $\mathrm{T}_{\max }$ & $\mathrm{C}_{\text {trough }}$ & $\mathrm{AUC}_{\tau}{ }^{\mathrm{a}}$ & $\mathrm{AUC}_{\mathrm{t}}$ & $\mathrm{AUC}_{\text {total }}$ \\
\hline \multirow{3}{*}{ Intravenous } & $m g / k g$ & & $n g / m l$ & $h$ & $n g / m l$ & $n g \cdot h / m l$ & $n g \cdot h / m l$ & $n g \cdot h / m l$ \\
\hline & 0.1 & 1 & $2575 \pm 176$ & $0.083(0.083,0.083)$ & $<\mathrm{LLOQ}$ & $9035 \pm 602$ & $9035 \pm 602$ & $41,753 \pm 2213^{\mathrm{b}}$ \\
\hline & & 5 & $2096 \pm 80$ & $0.083(0.083,0.083)$ & $9.62 \pm 1.39$ & $5159 \pm 301$ & $5611 \pm 429$ & $30,124 \pm 1112^{\mathrm{c}}$ \\
\hline \multirow{2}{*}{ Subcutaneous } & 0.5 & 1 & $911 \pm 432$ & $8(8,8)$ & $<$ LLOQ & $17,656 \pm 6700$ & $17,656 \pm 6700$ & $33,402 \pm 9204$ \\
\hline & & 4 & $1006 \pm 119$ & $2(2,8)$ & $10.0 \pm 1.25$ & $15,214 \pm 2529$ & $15,746 \pm 2601$ & \\
\hline
\end{tabular}

$N=3$ per treatment group, LLOQ $=1.00 \mathrm{ng} / \mathrm{ml}$.

Mean ( \pm S.D.) for all parameters except $\mathrm{T}_{\max }[\operatorname{median}(\min , \max )]$.

$\mathrm{a}_{\tau}=24$ hours for intravenous dosing regimen and 72 hours for subcutaneous dosing regimen.

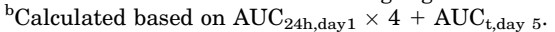

${ }^{\mathrm{c}}$ Calculated based on $\mathrm{AUC}_{24 \mathrm{~h} \text {,day } 1}+\mathrm{AUC}_{24 \mathrm{~h} \text {,day } 5} \times 3+\mathrm{AUC}_{\mathrm{t} \text {,day } 5}$.

of nemvaleukin were observed for all $\mathrm{CD}^{+} \mathrm{T}$ cell subsets (Fig. 4A). Numbers of terminal effector and effector memory $\mathrm{CD}^{+} \mathrm{T}$ cells were increased to a greater extent than of central memory and naïve $\mathrm{CD}^{+} \mathrm{T}$ cells, by approximately 20 - and 30-fold compared with 10- and 4-fold, respectively (Fig. 4B).

Changes in the number of central memory $\mathrm{CD} 4^{+} \mathrm{T}$ cells after repeat-dose administration of nemvaleukin (Supplemental Fig. 2) were generally similar to the observed changes in $\mathrm{CD}^{+} \mathrm{T}_{\text {regs. }}$.

Serum levels of proinflammatory cytokines were also measured, and may correlate with responses by particular immune cell populations. Transient elevation of IL-6 and IFN $\gamma$ was observed after both intravenous and subcutaneous administration of nemvaleukin and peaked at 2 hours (intravenous) and 8 hours (subcutaneous) postdosing (Supplemental Fig. 3). No notable increases in levels of IL-1 $\beta$, IL-8, or IL-10 were observed after intravenous or subcutaneous administration of nemvaleukin (data not shown).

\section{Discussion}

The amplification of antitumor $\mathrm{T}$ cell responses is a key component of the cancer immunity cycle and forms the basis of the rationale for the use of high-dose IL-2 in patients with metastatic melanoma or advanced renal cell carcinoma (Chen and Mellman, 2013; Clark et al., 2017; Buchbinder et al., 2019; Fishman et al., 2019). However, high-dose IL-2 therapy has been shown to induce expansion of both antitumor effector cell and $\mathrm{T}_{\text {reg }}$ populations, with greater expansion of $\mathrm{ICOS}^{+} \mathrm{T}_{\text {regs }}$ correlating with poor outcome of high-dose IL-2 therapy (Sim et al., 2014). In addition, maximal efficacy of recombinant IL-2 therapy in humans requires an intensive high-dose intravenous administration regimen, as demonstrated in a head-to-head phase III study comparing intravenous dosing regimens (McDermott et al., 2015). Nemvaleukin is designed to selectively activate antitumor $\mathrm{T}$ cell and NK cell populations over $\mathrm{T}_{\text {regs }}$, as was observed in mice and with human peripheral blood mononuclear cells in vitro. In addition, equivalent antitumor efficacy was observed after intravenous and subcutaneous administration of nemvaleukin in tumor-bearing mice (Lopes et al., 2020). The pathologic effects of recombinant IL-2 in monkeys are known to be predictive of pathogenesis in humans (Harada and Yahara, 1993; Gillies et al., 2011). As the in vitro potency for nemvaleukin on immune cell subsets found in peripheral blood were similar for cynomolgus monkeys and humans, the PK-PD relationship in cynomolgus monkeys is expected to inform dose selection and predict PD effects in humans. These studies conducted with cynomolgus monkeys set out to compare the PK and PD effects of single or repeated doses of nemvaleukin after intravenous or subcutaneous administration. An additional goal was to ascertain whether subcutaneous administration of nemvaleukin could achieve similar or more favorable PD responses versus intravenous administration in cynomolgus monkeys.

PK analysis showed that subcutaneous administration of nemvaleukin with less frequent dosing can achieve total systemic exposure and trough serum concentrations that are comparable to those achieved with daily intravenous administration, albeit with lower peak serum concentrations. Analysis of the PD effects of nemvaleukin on multiple immune cell subtypes (including circulating $\mathrm{CD}^{+} \mathrm{T}$ cells, $\mathrm{CD}^{+} \mathrm{T}$ cells, CD56 ${ }^{+} \mathrm{NK}$ cells, and $\mathrm{T}_{\text {regs }}$ ) revealed the selective expansion of potentially immunoprotective central memory, effector memory, and terminal effector $\mathrm{CD}^{+} \mathrm{T}$ cell and $\mathrm{CD}^{+} 6^{+} \mathrm{NK}$ cell populations after both intravenous and subcutaneous administration. It is worth noting that, in the current study, the overall expansion of $\mathrm{CD}^{+} \mathrm{T}$ cell and NK cell populations was similar between intravenous (once daily on days 1-5) and subcutaneous (on day 1 and day 4) dosing regimens, which correlated with similar total systemic exposure to nemvaleukin between the two dosing regimens.

Ki-67 protein expression was used as a marker of immune cell proliferation and, as such, has been validated and is widely used as a means of quantifying the dividing fraction of a given cell population (Scholzen and Gerdes, 2000; Sun and Kaufman, 2018). Our data show that the expanded populations of $\mathrm{CD} 8^{+} \mathrm{T}$ cells and NK cells that result from nemvaleukin administration are actively undergoing proliferation, whereas the population of $\mathrm{T}_{\text {regs }}$ showed less pronounced levels of proliferation. The comparatively modest expansion of total $\mathrm{T}_{\text {regs }}$ after administration of intravenous or subcutaneous nemvaleukin further supports its immunotherapeutic potential and distinguishes it from other IL-2-based therapies. The selective expansion of $\mathrm{CD} 8^{+} \mathrm{T}$ cells and NK cells by nemvaleukin, with limited impact on $\mathrm{T}_{\text {reg }}$ expansion, observed in mice (Lopes et al., 2020) and here in cynomolgus monkeys, is in marked contrast to the $\mathrm{T}_{\text {reg-biased }}$ immune profile induced by recombinant IL-2 in mice (Lopes et al., 2020), monkeys (Bell et al., 2015), and humans (Sim et al., 2014). Indeed, the propensity of low-dose recombinant IL2 to elicit the expansion of $\mathrm{T}_{\text {regs }}$ has prompted its use as a treatment of autoimmune diseases, such as rheumatoid arthritis, which are characterized by deficiencies of $\mathrm{T}_{\text {regs }}$ (Ye et al., 2018).

Analysis of serum concentrations of proinflammatory cytokines showed transient elevation of both IL- 6 and IFN $\gamma$ that peaked at 2 hours and 8 hours after intravenous and subcutaneous administration of nemvaleukin, respectively. After 
Fig. 3. Effect of repeated intravenous $(0.1 \mathrm{mg} / \mathrm{kg}$ for 5 consecutive days) or subcutaneous $(0.5 \mathrm{mg} / \mathrm{kg}$ on days 1 and 4) administration of nemvaleukin on (A) total $\mathrm{CD} 8^{+} \mathrm{T}$ cells and $\mathrm{CD} 56^{+} \mathrm{NK}$ cells and (B) $\mathrm{CD}^{+} \mathrm{T}_{\text {regs }}$, and (C) the proportion of cells expressing the cell proliferation marker Ki-67. Data shown are the mean \pm S.E. of the mean (S.E.M.) with $N=3$ per treatment group. Fold changes were calculated relative to predose levels for individual monkeys.
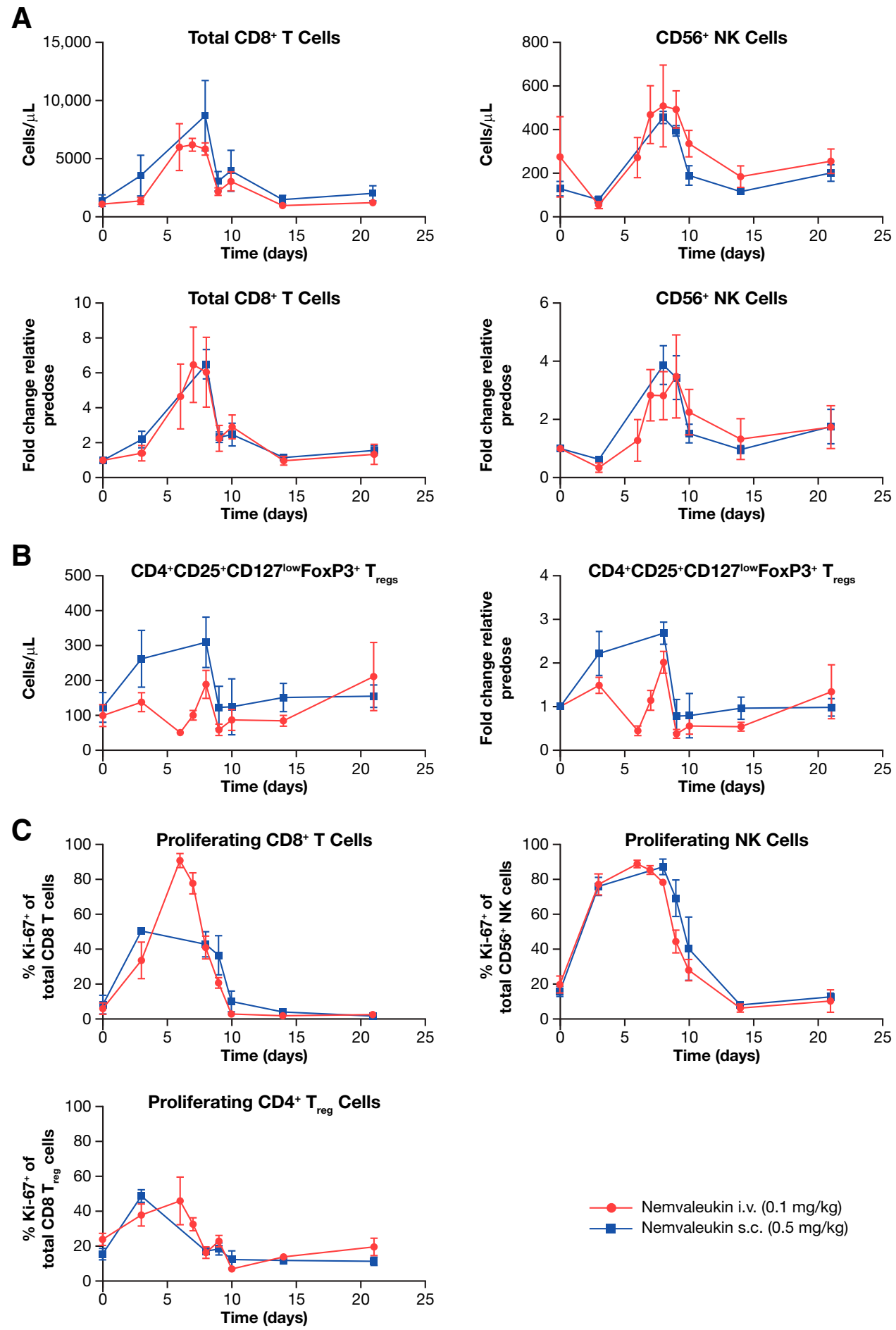

repeat dosing, levels of IL-6 trended higher after intravenous administration relative to subcutaneous administration, which could be attributed to the higher observed $\mathrm{C}_{\max }$ for nemvaleukin after intravenous administration compared with subcutaneous administration. These cytokine data might suggest better tolerability with a subcutaneous treatment regimen, given the association between IL-6 and loss of endothelial barrier function and, by implication, vascular leakage (Alsaffar et al., 2018; Narazaki and Kishimoto, 2018). IFN $\gamma$ production by immune effector cells is associated with antitumor efficacy (Ivashkiv, 2018); therefore, the induction of IFN $\gamma$ suggests that nemvaleukin might promote the activation of cells associated with antitumor immune responses after both intravenous and subcutaneous administration.

In conclusion, subcutaneous administration of nemvaleukin can achieve total systemic exposure similar to that of intravenous administration, with less frequent dosing and a lower $\mathrm{C}_{\max }$, resulting in similar expansion of $\mathrm{CD}^{+} \mathrm{T}$ cells and 

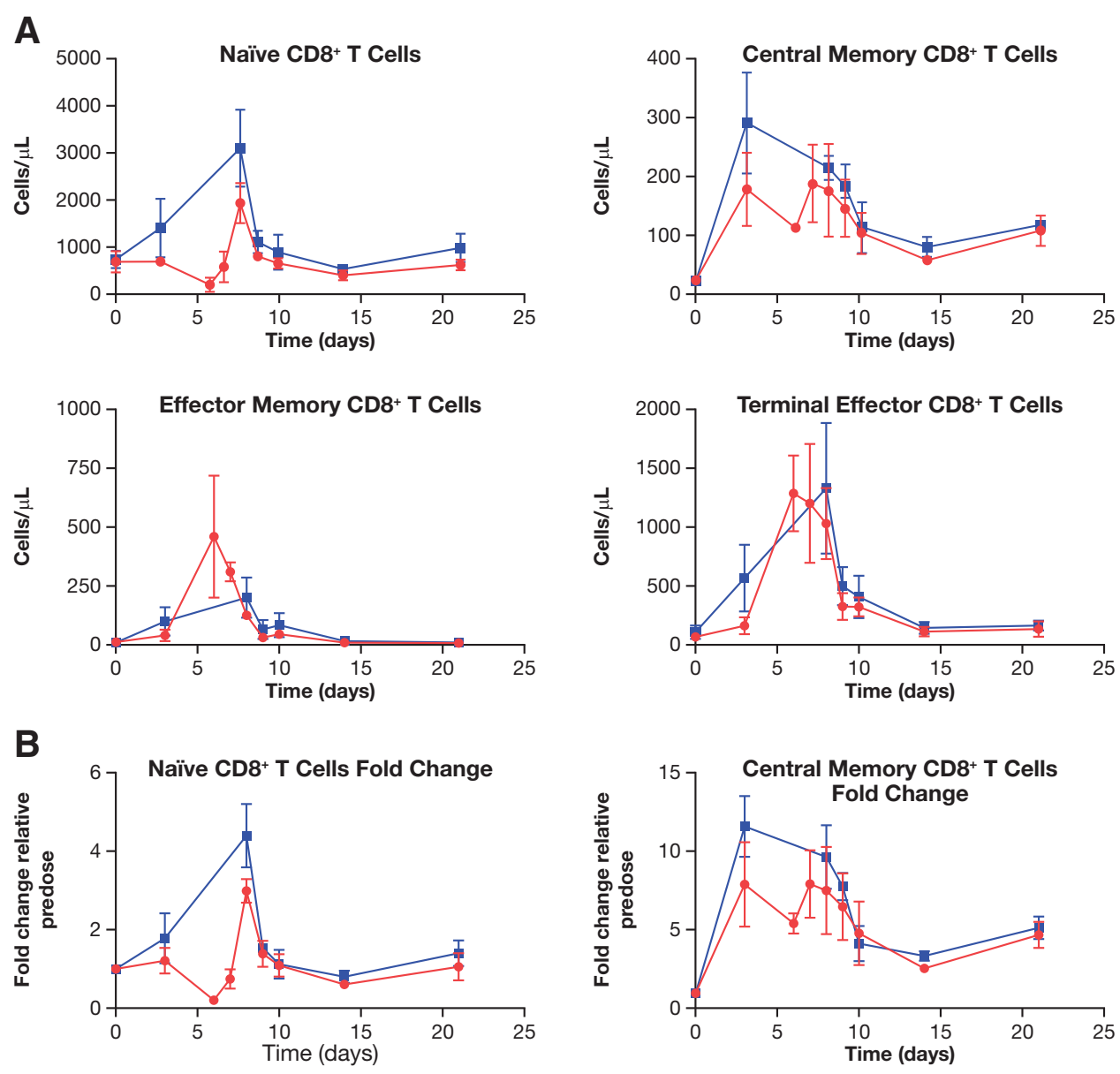

Fig. 4. Effect of repeated intravenous $(0.1 \mathrm{mg} / \mathrm{kg}$ for 5 consecutive days) or subcutaneous $(0.5 \mathrm{mg} / \mathrm{kg}$ on days 1 and 4$)$ administration of nemvaleukin on $\mathrm{CD} 8^{+}$ $\mathrm{T}$ cell subsets in terms of (A) cell numbers and (B) fold change relative to predose levels. Data shown are the mean \pm S.E.M. with $N=3$ per treatment group.
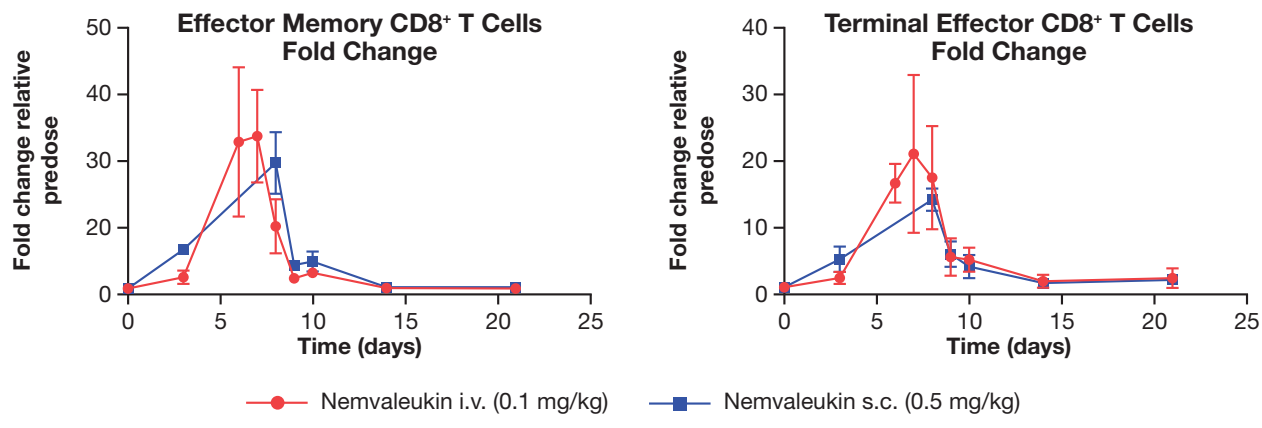

$\mathrm{CD}^{+} 6^{+} \mathrm{NK}$ cells with minimal expansion of $\mathrm{CD} 4^{+} \mathrm{T}_{\text {regs. }}$ The $\mathrm{PK}$ and $\mathrm{PD}$ data in monkeys reported here support clinical evaluation of intravenous and subcutaneous administration of nemvaleukin in humans with advanced solid tumors. In addition to the ongoing phase I/II ARTISTRY-1 first-in-human study of intravenous nemvaleukin (NCT02799095), the PD, PK, safety, and efficacy of subcutaneous administration of nemvaleukin are currently under investigation in the phase I/II ARTISTRY-2 study (NCT03861793). The selection of subcutaneous nemvaleukin dose and dosing frequency in ARTISTRY-2 was determined from predictions (manuscript in development) based on the observed PK-PD relationship from ARTISTRY-1 and in monkeys after intravenous and subcutaneous routes of administration. In the ARTISTRY-2 study, subcutaneous nemvaleukin is given as a single agent or in combination with pembrolizumab to patients with selected advanced or metastatic solid tumors. The subcutaneous route of administration might provide an alternative administration option for patients.

\section{Acknowledgments}

Medical writing support was provided by Eleanor Finn from Parexel International and was funded by Alkermes, Inc.

\section{Authorship Contributions}

Participated in research design: Lopes, Sun, Losey. Conducted experiments: Lopes, Sun, Flick, Murphy.

Contributed new reagents or analytic tools: Lopes, Sun, Flick, Murphy, Losey.

Performed data analysis: Lopes, Sun, Flick, Murphy, Losey.

Wrote or contributed to the writing of the manuscript: Lopes, Sun, Flick, Murphy, Losey. 


\section{References}

Ahmadzadeh M and Rosenberg SA (2006) IL-2 administration increases CD4+ CD25(hi) Foxp3 + regulatory T cells in cancer patients. Blood 107:2409-2414.

Alsaffar H, Martino N, Garrett JP, and Adam AP (2018) Interleukin-6 promotes a sustained loss of endothelial barrier function via Janus kinase-mediated STAT3 phosphorylation and de novo protein synthesis. Am J Physiol Cell Physiol 314:C589-C602. Amaria RN, Reuben A, Cooper ZA, and Wargo JA (2015) Update on use of aldesleukin for treatment of high-risk metastatic melanoma. ImmunoTargets Ther 4:79-89.

Antony PA and Restifo NP (2005) CD4+CD25 + T regulatory cells, immunotherapy of cancer, and interleukin-2. J Immunother 28:120-128.

Atkins MB, Lotze MT, Dutcher JP, Fisher RI, Weiss G, Margolin K, Abrams J, Sznol M, Parkinson D, Hawkins M, et al. (1999) High-dose recombinant interleukin 2 therapy for patients with metastatic melanoma: analysis of 270 patients treated between 1985 and 1993. J Clin Oncol 17:2105-2116.

Bell CJ, Sun Y, Nowak UM, Clark J, Howlett S, Pekalski ML, Yang X, Ast O, Waldhauer I, Freimoser-Grundschober A, et al. (2015) Sustained in vivo signaling by long-lived IL-2 induces prolonged increases of regulatory T cells. J Autoimmun 56:66-80.

Boyman O and Sprent J (2012) The role of interleukin-2 during homeostasis and activation of the immune system. Nat Rev Immunol 12:180-190.

Buchbinder EI, Dutcher JP, Daniels GA, Curti BD, Patel SP, Holtan SG, Miletello GP, Fishman MN, Gonzalez R, Clark JI, et al. (2019) Therapy with high-dose interleukin-2 (HD IL-2) in metastatic melanoma and renal cell carcinoma following PD1 or PDL1 inhibition. J Immunother Cancer 7:49.

Chen DS and Mellman I (2013) Oncology meets immunology: the cancer-immunity cycle. Immunity 39:1-10.

Choudhry H, Helmi N, Abdulaal WH, Zeyadi M, Zamzami MA, Wu W, Mahmoud MM, Warsi MK, Rasool M, and Jamal MS (2018) Prospects of IL-2 in cancer immunotherapy. BioMed Res Int 2018:9056173.

Clark JI, Wong MKK, Kaufman HL, Daniels GA, Morse MA, McDermott DF, Agarwala SS, Lewis LD, Stewart JH, Vaishampayan U, et al. (2017) Impact of sequencing targeted therapies with high-dose interleukin-2 immunotherapy: an analysis of outcome and survival of patients with metastatic renal cell carcinoma from an on-going observational IL-2 clinical trial: PROCLAIM ${ }^{\mathrm{SM}}$. Clin Genitourin Cancer 15:31-41.e4.

Fishman M, Dutcher JP, Clark JI, Alva A, Miletello GP, Curti B, Agarwal N, Hauke $\mathrm{R}$, Mahoney KM, Moon H, et al. (2019) Overall survival by clinical risk category for high dose interleukin-2 (HD IL-2) treated patients with metastatic renal cell cancer (mRCC): data from the PROCLAIM ${ }^{\text {SM }}$ registry. J Immunother Cancer 7:84.
Gillies SD, Lan Y, Hettmann T, Brunkhorst B, Sun Y, Mueller SO, and Lo KM 2011) A low-toxicity IL-2-based immunocytokine retains antitumor activity despite its high degree of IL-2 receptor selectivity. Clin Cancer Res 17: 3673-3685.

Harada Y and Yahara I (1993) Pathogenesis of toxicity with human-derived interleukin-2 in experimental animals. Int Rev Exp Pathol 34 Pt A:37-55.

Ivashkiv LB (2018) IFN $\gamma$ : signalling, epigenetics and roles in immunity, metabolism, disease and cancer immunotherapy. Nat Rev Immunol 18:545-558.

Lopes JE, Fisher JL, Flick HL, Wang C, Sun L, Ernstoff MS, Alvarez JC, and Losey HC (2020) ALKS 4230: a novel engineered IL-2 fusion protein with an improved cellular selectivity profile for cancer immunotherapy. J Immunother Cancer 8:8.

McDermott DF, Cheng SC, Signoretti S, Margolin KA, Clark JI, Sosman JA, Dutcher JP, Logan TF, Curti BD, Ernstoff MS, et al. (2015) The high-dose aldesleukin "select" trial: a trial to prospectively validate predictive models of response to treatment in patients with metastatic renal cell carcinoma. Clin Cancer Res 21:561-568.

Narazaki M and Kishimoto T (2018) The two-faced cytokine IL-6 in host defense and diseases. Int J Mol Sci 19:3528.

Scholzen T and Gerdes J (2000) The Ki-67 protein: from the known and the unknown. J Cell Physiol 182:311-322.

Sim GC, Martin-Orozco N, Jin L, Yang Y, Wu S, Washington E, Sanders D, Lacey C, Wang Y, Vence L, et al. (2014) IL-2 therapy promotes suppressive ICOS+ Treg expansion in melanoma patients. J Clin Invest 124:99-110.

Skrombolas D and Frelinger JG (2014) Challenges and developing solutions for increasing the benefits of IL-2 treatment in tumor therapy. Expert Rev Clin Immunol 10:207-217.

Sun X and Kaufman PD (2018) Ki-67: more than a proliferation marker. Chromosoma 127:175-186.

Sun Z, Ren Z, Yang K, Liu Z, Cao S, Deng S, Xu L, Liang Y, Guo J, Bian Y, et al. (2019) A next-generation tumor-targeting IL-2 preferentially promotes tumor-infiltrating $\mathrm{CD}^{+}{ }^{-}$T-cell response and effective tumor control. Nat Commun 10:3874

Waldmann TA (2006) The biology of interleukin-2 and interleukin-15: implications for cancer therapy and vaccine design. Nat Rev Immunol 6:595-601.

Ye C, Brand D, and Zheng SG (2018) Targeting IL-2: an unexpected effect in treating immunological diseases. Signal Transduct Target Ther 3:2.

Address correspondence to: Heather C. Losey, Alkermes, Inc. 852 Winter St. Waltham, MA 02451. E-mail: heather.losey@alkermes.com 